\title{
Filial Obligations: A Contextual, Pluralist Model
}

\author{
Anders Schinkel
}

Received: 29 August 2011/Accepted: 16 May 2012/Published online: 12 June 2012

(C) The Author(s) 2012. This article is published with open access at Springerlink.com

\begin{abstract}
In this article I investigate the nature and extent of filial obligations. The question what (adult) children owe their parents is not only philosophically interesting, but also of increasing relevance in ageing societies. Its answer matters to elderly people and their adult children, and is relevant to social policy issues in various ways. I present the strongest arguments for and against three models of filial obligations: the 'past parental sacrifices' model, the 'special relationship' model, and the conventionalist model. There is something to be said-and after consideration of objections something remains to be said-for all three models. In other words: filial obligations have more than one source, and an adequate model of filial obligations should reflect this. On its own, each of the above models is one-sided. They also fail to show the connections between the question of filial obligations and various other issues, such as issues of gender justice, the extent of institutionalization of eldercare, and social conventions regarding filial responsibility. Therefore, I integrate what I think we should keep from the aforementioned models into a contextual, pluralist model, which places filial obligations in a broader social and cultural context and relates them to issues of social justice. The model also highlights the difference between general and specific filial obligations, and the factors that determine their nature and extent, thus enabling a deeper and more comprehensive understanding of filial obligations.
\end{abstract}

Keywords Children · Filial obligations · Filial responsibility · Parents · Special obligations

\footnotetext{
A. Schinkel $(\square)$

Faculty of Psychology and Education, VU University Amsterdam, Van der Boechorststraat 1, 1081 BT Amsterdam, The Netherlands e-mail: a.schinkel@vu.nl
} 


\section{Introduction}

Since Jane English (1979) answered the question 'What do grown children owe their parents?' with the provocative assertion that they owe them nothing, philosophical debate about filial obligations has been ongoing. Not that this is all due to the stimulating nature of English's essay, of course. That this debate still continues after 30 years has to do, rather, with three things: firstly, the continuing and even increasing practical relevance of the subject; secondly, the philosophical interest of the subject; and thirdly, the simple fact that the topic is still far from being exhaustively explored. The present article as a whole is intended to support the latter assertion, so I will limit myself to a brief elaboration of the first two points here.

The debate about filial obligations is set against the background of ageing (Western) societies. In most countries in the world the number of old people relative to the rest of the population has been increasing for some time, and is expected to increase significantly in the coming decades, making the questions who will and who should care for dependent elderly and ensure elderly people's important needs are met all the more pertinent (Human Development Report 2009, pp. 191ff, table L: 'Demographic trends'; Gavrilov and Heuveline 2003). A common government response to population ageing and the attendant increase of expenditure on the elderly is to shift some of the burden of caring for (and financially supporting) the elderly (back) to the elderly themselves or to a third party. Several countries, such as Germany and the Netherlands, have raised the pension age. With regard to eldercare, the general trend in Europe is to shift from institutional care to (formal or informal) homecare, and from inkind to cash transfers (Simonazzi 2010, p. 135; Rummery 2010; Le Bihan and Martin 2010). The result is an increased burden for the children, financially, emotionally, in terms of time and energy, or a combination of these things. ${ }^{1}$

Social policies increasingly rely on filial responsibility, but at the same time, over the last couple of decades, society has changed in ways that leave less room for the fulfilment of filial obligations. Women, who traditionally did most of the caring for elderly parents, increasingly participate in the labour market, leaving them less time (and sometimes less energy) for caregiving. It is therefore not really surprising that it seems some women no longer perceive it as 'natural' to care for dependent family members (Guberman and Lavoie 2010). ${ }^{2}$ Furthermore, various studies suggest that adult children are most willing to provide emotional support, and least willing to provide financial support (with caregiving somewhere in-between) ( $\mathrm{Ng} 2002$; Lye 1996, p. 96); it is worth noting that this seems to be matched by most elderly's preferences (Callahan 1985, p. 33; Lye 1996, p. 96). All this suggests there are tensions between current social policies regarding the elderly and adult children's ability and willingness to care for their elderly parents.

The existence of non-Western ethnic minorities in many Western countries provides further poignancy to the question of filial obligations. In the Netherlands, for instance, especially Turkish and Moroccon immigrant elderly hold considerably

\footnotetext{
${ }^{1}$ Cf. Aronson and Neysmith (1997) for the shift from institutional to community-based care in Canada; they also note this is the trend in 'most western industrialized nations'.

2 On this perceived 'naturalness' see Holstein (2000, pp. 236ff.).
} 
more demanding views of filial obligation than native Dutch elderly, but it is very well conceivable that these views and the concomitant obligations will, to some extent, clash with the actual behaviour of their children (De Valk and Schans 2008).

In sum, then, questions regarding the nature and extent of filial obligations will matter to both elderly people and their adult children, and they are relevant to social policy issues in various ways (cf. Keller 2006, pp. 254-255; Nelson 2002; Collingridge and Miller 1997; Wicclair 1990, p. 164). But they are also philosophically interesting, for instance with regard to the debate between adherents to 'impartialist' moral theories and theories that make room for partiality towards those with whom one has a special relation of some kind (Keller 2006, p. 255; Sommers 1986), and with regard to the difference between moral contextualism and moral relativism.

In what follows I will first (in Sect. 2) present the strongest arguments for and against three models of filial obligations: the 'past parental sacrifices' model, the 'special relationship' model, and the conventionalist model. All three come in different variants, with different strengths and weaknesses. ${ }^{3}$ In Section 3 I will integrate what I think we should retain from these models into a contextual, pluralist model, which places filial obligations in a broader social and cultural context and relates them to issues of social justice. ${ }^{4}$ There is something to be said-and after consideration of objections something remains to be said-for all three models. In other words: filial obligations have more than one source, and an adequate model of filial obligations should reflect this.

\section{Three Models of Filial Obligations}

Filial obligations, if the term is to mean anything, are the special obligations that children have towards their parents; and in this article I am specifically concerned with the obligations of adult children towards their elderly (or otherwise in some respect needy) parents. If it were the case that there are only general obligations towards elderly people, i.e., obligations that every adult has towards elderly people, then people would also have them towards their parents, but these would not be filial obligations, because they would not be special obligations. Filial obligations are

\footnotetext{
3 Collingridge and Miller (1997) discuss a 'reciprocity model', 'needs-based model', 'friendship model', and 'conventionalist model'. I see the reciprocity model as one variant of the past parental sacrifices model (I take this name from Wicclair 1990), the gratitude model being the other. I do not discuss the needs-based model, for it does not ground or explain special (filial) obligations, but only general obligations. Li (1997) distinguishes between 'English's Friendship Model', 'Belliotti's Contribution to Self Principle', 'Narveson's Prudent Investor Thesis', 'Sommers' Conventional Expectation Thesis', 'Blustein's Gratitude Theory' and 'The Confucian Alternative'. I take the latter to be a type of conventionalist approach, and I leave Belliotti's and Narveson's approaches aside because they have (rightly, I think) played no significant role in the debate about filial obligations. Keller (2006) also provides an overview of different models (or 'theories', as he calls them): the debt theory, the gratitude theory, and the friendship theory, to which he adds his own 'special goods' theory (which shows strong similarities to Claudia Mills' approach in Mills 2003). I subsume both the friendship theory and the special goods theory under the heading of the 'special relationship' model.

${ }^{4}$ Relations with issues of social justice are also discussed by Callahan (1985) and Thompson (2003); Jecker (2002) discusses filial obligations themselves in terms of duties of justice.
} 
obligations that only (adult) children have towards their parents, obligations that they have as their parents' children. ${ }^{5}$

The three models I discuss below all (attempt to) provide an account of the basis or source(s) of filial obligations, of that which justifies the special moral demands made of children by or on behalf of their parents. In doing so, they also give a (partial) account of the nature of filial obligations, of what is owed ${ }^{6}$ (e.g. gratitude, respect, intimacy) and the kinds of things children are bound to provide or to do (e.g. emotional or financial support, keeping in touch, caregiving), and their extent (limited or unlimited, equal to what parents did for them or not, depending on ability and/or need, etc.).

\subsection{The Past Parental Sacrifices Model}

Wicclair considers past parental sacrifices 'arguably the most promising' candidate source of ethical obligations. This account, which may be seen as the 'traditional' account, states simply that because parents make considerable sacrifices for their children (which they do not make for others) in promoting their well-being, education, et cetera, children owe it to their parents to give them 'special consideration' 'when they become old and dependent' (Wicclair 1990, p. 165).

\footnotetext{
${ }^{5}$ I deliberately leave open here the question whether it is for contingent or noncontingent reasons that children have these obligations towards their parents. For a duty to reciprocate, for instance, it may be neither here nor there that it is one's parents to whom one owes this duty-that would depend on what one has to reciprocate for. Moreover, the fact that parents tend to make great sacrifices with a view to their children's well-being could be seen as contingently related to parenthood, depending on what one's definition of 'parenthood' is, and how normative it is (but see also footnote 16). In another article, it may be worth considering whether the different models of filial obligations can be categorized according to their answers to the questions (1) whether the obligation-engendering factors are intrinsic to the parentchild relationship or not, and (2) whether the obligations are special instances of general obligations (such as the duty of reciprocity) or obligations of a special kind-obligations of a kind one can only have towards one's parents. The second question would have to be subdivided into question 2a, for general filial obligations, and $2 \mathrm{~b}$, for specific filial obligations (see Section 3 for this distinction).

${ }^{6}$ In the literature on filial obligations, what children owe to their parents is not discussed in terms of negative and positive duties; except in Sommers (1986, p. 446; see 2.3) the distinction is not even mentioned, and I, as one anonymous referee for The Journal of Ethics observed, do not make use of it either. There are a number of reasons not to pursue the distinction when trying to determine whether there are (special) filial obligations and if so, of what nature and extent. One is that-beyond the intuitive difference between negative and positive duties-one would have to commit oneself to a specific position concerning (the relevance of) the difference, about which there is much debate; this would detract from the intended topic of discussion. First we need to determine whether there is a basis for claiming that children have special obligations to their parents; as a next step we could discuss whether the distinction between positive and negative duties applies to them. Another, but similar, reason is that one would easily get tied up in a debate about the question whether special duties must be seen as a subclass of positive duties or not, or, more generally, about the relationship between special duties and positive/negative duties (cf. Malm 1991, p. 188 and footnote 5). That noted, it is probably true that most authors on filial obligations see them as duties to do good or prevent harm (positive duties) rather than duties not to cause harm (negative duties). And so, in his defence of the moral relevance of the act-omission distinction, does Abelson (1982). I believe this is correct as far as general filial obligations go (for which, see Section 3); children have no other (general) negative duties towards their parents than anybody has to anyone else. But there may be specific filial obligations of a negative kind, related to the specific ways in which parents are vulnerable to children. That, however, would be a topic for another article. All the concrete examples of filial obligations I give in the present article concern positive duties.
} 
One variant holds that children have duties of indebtedness or reciprocity (Post 1989), another that they have duties of gratitude (Berger 1975, p. 300; Blustein 1982; Callahan 1985; Zola 2001). ${ }^{7}$ Duties of indebtedness entail that what A owes B is (1) roughly equivalent to what A received from B; (2) this is more or less precisely specifiable, and (3) it is possible to determine when the debt has been discharged. With duties of gratitude these conditions do not obtain (Wicclair 1990, p. 175). ${ }^{8}$

The past parental sacrifice model has a strong intuitive appeal, and it is not surprising that, traditionally, it has played an important part in Western accounts of filial obligations, as it still does in many parts of the world. ${ }^{9}$ Generally speaking, we consider it normal and fitting when people feel grateful or even indebted to people who did much, or made a considerable effort, to benefit them in some way-and (fortunately) many people feel their parents did do (and perhaps still do) many things to their benefit. The idea that all the things parents do with a view to their children's well-being, happiness, or perhaps their salvation-all the time, energy, and resources they spend-counts for nothing when it comes to determining children's obligations to their parents later in life will strike many people as odd, not to say vile. Moreover, it seems odd to say that there is no relation at all between the nature and extent of filial obligations and the magnitude of parental sacrifices or efforts on behalf of their children. Surely, the former depend on the latter at least to some extent?

Plausible as this may seem, powerful objections have been raised against the past parental sacrifices model of filial obligations (in one or both of its main variants). I will summarize what I take to be the strongest objections:

1. Whereas parents choose to take upon themselves the obligations that come with parenthood, children have no choice in the matter. They do not ask to be born, and since they are not there when their parents decide to have them, they cannot reject the sacrifices their parents will make on their behalf, and therefore cannot voluntarily accept filial obligations. This also means that there cannot be an implicit contract between parents and children that requires the latter to reciprocate for what the former did for them (Blustein 1982; Levy and Gross 1979; Goodin 1985, pp. 83-86; Thompson 2003).

\footnotetext{
7 For Post, reciprocity includes the elements of gratitude and proportionality; Zola believes filial obligations to be obligations of gratitude, but sees gratitude as the form reciprocity should take. For the distinction between indebtedness or reciprocity on the one hand and gratitude on the other, see Wicclair (1990), Gerber (1990), and Nelson (2002).

8 Interestingly, Keller (2006, pp. 260-262) contrasts filial duties with duties of gratitude on the ground (among others) that the former, unlike the latter, are 'ongoing and open-ended' and can be 'very demanding'. I take it that Keller's and Wicclair's views are more compatible than they seem. They both make the point that duties of gratitude have no clearly determinable content (which also means there can be no equivalence relation), and Wicclair's point that with duties of gratitude it is impossible to say when they have been discharged should not be taken to mean they are ongoing, open-ended and demanding. However, Wicclair takes filial obligations to be examples of duties of gratitude, and Keller rejects the gratitude model.

9 A common reference in the literature is Blackstone's Commentaries on the Laws of England, written between 1765 and 1769, which state that '[t]he duties of children to their parents arise from a principle of natural justice and retribution' (Blackstone 1893, Book I, ch. 16, Section I.3). From the explanation it is clear that filial obligations are owed in return for what the parents did for their children, such as giving them existence, protecting them, and providing for them (cf. Callahan 1985, p. 33).
} 
2. When parents decide to (try to) have children, they voluntarily take upon themselves the obligation to care for their children, to protect them, provide for them, et cetera. ${ }^{10}$ If they do not do these things, they fail to do their duty as parents. Since they are merely doing their duty, the children incur no special obligations towards them for providing these goods and services (Daniels 1988, pp. 30-31; Simmons 1979, p. 182). Only when parents go beyond the call of duty can reciprocity or gratitude be owed (Blustein 1982, p. 182; Callahan 1985, p. 35).

3. The language of 'owing' seems out of place with regard to parent-child relations, especially or at least when this is understood in terms of indebtedness and reciprocal rights and duties (English 1979; Blustein 1982; Goodin 1985, p. 89; Wicclair 1990, pp. 172-173). In relations of love and/or friendship, which is what parent-child relationships should be (like), one does not and should not keep track of what one person has done for another, and how much is owed in return. Moreover, 'transactions' between family members do not leave the parties and their relation the same when they are completed; this distinguishes them from relations of indebtedness, where, after payment of the debt, the relation returns to what it was before the debt was incurred (Goodin 1985, p. 89).

4. Parental sacrifices are normally, and for the most part, motivated by love and affection, not made as a favour, and therefore they require no return (English 1979). It may be that parental sacrifices_or actually: parental love-leads to mutual love, affection, or friendship, which means that children will also aid their parents out of love, but this is not like the discharge of a duty.

5. The reciprocity model implausibly suggests that (elderly) parents' actual needs make no difference to what children owe them. Poor parents who could provide only minimal (material) benefits to their children are owed very little when they are old and needy, and rich parents are owed a lot, even when they are still rich and not needy at all. This cannot be right (Collingridge and Miller 1997, p. 124; Goodin 1985, pp. 84, 88). (This is the only objection to the past parental sacrifices model that does defend the notion of filial obligations.)

The above arguments, plausible as they may sound, are not without their problems. First of all, it seems very well possible involuntarily to incur obligations (Wang 1998; Wicclair 1990, p. 167; Collingridge and Miller 1997, p. 127). Wang uses the example of an able swimmer (Fred) who sees that a child (Sheila) is drowning in a swimming pool; clearly, Fred has a moral obligation to save Sheila, even though he was never in a position to reject or consent to such an obligation. It is forced upon him by the situation, but in no way does this deter from the fact that it is his duty. So the absence of a voluntary choice to accept (future) obligations is not in itself an argument against (the past parental sacrifice view of) filial obligations. Wicclair also argues against the voluntarist objection, which he summarizes as the objection that 'parental sacrifices are generally unrequested' (Wicclair 1990, p. 166). He uses an example that relates directly to filial obligations, introducing the twins Mindy and Sarah, whose parents made them take expensive violin lessons. Mindy enjoyed them and became a child prodigy, Sarah was forced to take the lessons against her expressed will. Mindy,

${ }^{10}$ For the sake of simplicity I will disregard cases of involuntary parenthood here. 
Wicclair (1990, p. 167) argues, "cannot plausibly support her claim that she owes her parents nothing by pointing out that she never requested lessons. Since she wanted and valued lessons, it would be disingenuous if she were to assert, 'Since I never asked for lessons, I don't owe my parents anything for providing them.'” And although Sarah could argue that she does not owe her parents anything, this is not because she did not ask for their sacrifice, but because she was forced to take the lessons against her will, so Wicclair argues. The crucial point of Wicclair's example is that Mindy got something she wanted, although she did not request it. A similar but slightly different argument is that of hypothetical consent: sometimes one receives benefits without being in a position to reject them or consent to them, but one would have consented to them if one had been in the position to do so (Li 1997, p. 212; Collingridge and Miller 1997, p. 127). Whether the obligations incurred in this way are obligations of reciprocity or 'merely' of gratitude remains to be determined; the point is that the voluntarist objection to the past parental sacrifices model does not succeed in excluding either. ${ }^{11}$

It may be true that doing one's moral duty does not normally engender entitlements. My neighbour has a right to privacy, which I have a duty to respect. If I 'do' my (negative) duty in this regard, this does not entitle me to anything. I cannot ask my neighbour for anything in return; his duty to respect my privacy must not be understood in this way, for it is simply based in the same right to privacy we (inhabitants of constitutional democracies) all enjoy. Even if I save a child from drowning (in a situation where I have a moral duty to do so), I am not entitled to the child's or its parents' gratitude. Yet here it seems that talk of obligation on their part is not wholly out of place. That I cannot claim their gratitude does not mean one cannot say they ought to be grateful (and show it). ${ }^{12}$

So what about parental duties? The second objection listed above seems fair enough, insofar as it entails that children do not have to feel especially grateful to their parents for providing them with what they owe them as a matter of justice (minimally adequate food and clothes, for instance, and a minimal education), assuming the parents are able to provide these things. But beyond such examples our intuitions become blurred. ${ }^{13}$ Wicclair seems right to point out that it "is not clear how many of the sacrifices that parents make for their children fall within the boundaries of "parental duties"' (Wicclair 1990, p. 169), and that therefore "the

\footnotetext{
11 This holds even if it may be true that filial obligations cannot be understood in terms of an implicit contract. Without (implicit) consent there can be no (implicit) contract, but without consent there can be obligations.

12 This is in line with Berger's (1975) idea of gratitude as a response to benevolence.

13 One referee for The Journal of Ethics rightly remarked that it is not a matter of course that parents provide their children with the minima in terms of food, clothing, housing, education, et cetera. Even in affluent countries there are parents who abandon their children or otherwise fail in their minimal duties as parents. The reviewer suggested that therefore, some gratitude might be merited by those parents who do fulfil these minimal duties (but nothing more). I disagree. If parents able to fulfil these duties fail to do so, children are treated unjustly; it would be appropriate to say their rights are violated, giving them cause for serious complaint. Children do not have to be grateful for not having their rights violated. The situation becomes different when poor parents provide their children only with the aforementioned minima, simply because that is all they can afford, but do so with love and care, and so on. For those immaterial 'goods', which parents are also commonly expected to provide, some gratitude seems appropriate, as I argue in the remainder of the paragraph.
} 
force of the statement [that children owe parents nothing for sacrifices beyond the requirements of duty; AS] is not clear" (Wicclair 1990, p. 170). I would also suggest that, whereas in some cases duties are defined in a way that makes it easy to fulfil them or difficult to fail in them, so that everyone expects everyone else to do their duty in those cases, there are also many situations in which what is generally seen as within the bounds of duty is nevertheless much more demanding. We praise people who do their duty under difficult circumstances-the obvious objection here is that, under such circumstances, doing one's duty (i.e., what is defined as one's duty under normal circumstances) may, paradoxically, be beyond the call of duty. But parenthood is not a clearcut case. It is not at all a matter of course that people manage to do all that is expected of them as parents, for we expect parents to be loving, caring, supportive, et cetera, under almost any circumstances. For this reason it does not seem odd to praise parents who 'do their duty' (if this is broadly defined, as it commonly is, rather than narrowly), and it seems there is at least room for obligations of gratitude here. ${ }^{14}$

It is true that family relations are very different from business relations. One does not and should not keep track of the flows of benefits and sacrifices. Yet this obvious truth is far too little proof to establish that 'the language of owing' is wholly out of place with regard to, or even in (and this is a different thing), family relationships. I agree with Post's (1989, p. 319) statement that “[j]ustice and proportionality are as relevant to family life as they are to all forms of social interaction". In good family relationships benefits can flow one way for a considerable length of time before anyone objects, but not endlessly. At some point, the patient benefactor will start to notice the discrepancy between 'what goes out' and 'what comes in', and will begin to feel that the other ought to reciprocate. Reciprocity is an important aspect of family relations. Furthermore, it makes perfect sense to talk of justice in regard to the family; in fact, it may be a crucial part of children's moral education that family relations are just and perceived by them to be so, and even that this is made explicit by the parents (Okin 1989, pp. 17ff.). So the third objection to the past parental sacrifices model is a serious overstatement: one cannot move from the observation that family interactions are unlike business transactions to the view that the language of owing is wholly out of place there, let alone in reflection on the moral aspects of family relations.

The same goes for the fourth objection, that parental sacrifices are motivated by love, rather than made with a view to reciprocation. Although the observation itself is largely correct-though it may romanticize the parent-child relationship somewhat-it cannot support the conclusion that parental sacrifices cannot give rise to filial obligations. Keller (2006, p. 255) notes that the fact that children should do certain things for their parents willingly and out of love, rather than from a sense of duty, is irrelevant to the question whether filial duties exist. The same applies here: that parents are motivated by love does not mean they are not doing their duty,

\footnotetext{
14 For a critique of the notion of obligations of gratitude, see Wellman (1999) who defends the idea that gratitude is a virtue.
} 
nor does it mean that children cannot incur any obligations as a result of their parents' sacrifices and efforts. ${ }^{15}$

Finally, if it were true that the reciprocity model implies that parental needs are irrelevant to the nature and extent of filial obligations, this would be a powerful objection indeed (though not one against filial obligations as such). But it is not at all clear that it is true. It seems to presuppose a rather simplistic view of reciprocity - as indeed did the third objection - as requiring the return of a benefit of exactly the same absolute size as the benefit received. Goodin (1985, p. 84), for instance, attempts to back up his argument with the rhetorical force of this example: "[W]e would (...) be most reluctant to say (...) that children whose parents supported them for 21 years have a sixteen percent greater debt to their parents than those who moved out of the family home at age eighteen." A more nuanced view of reciprocity is also possible: one could argue, for instance, that when poor parents aided their children according to their own ability and their children's need, reciprocity requires that children do the same for their parents when their parents are in need. This seems to be a (more) sensible view of proportionality-and it is perfectly compatible with, indeed requires, attention to parental needs. Furthermore, it seems as odd to deny any relation between the magnitude of parental sacrifices and the extent of filial duties, as to say that the extent of parental needs makes no difference to children's obligations. This is why some authors, as we have seen, argue that children incur obligations when parents go beyond the call of duty. But as pointed out above, it is unclear where the limits of parental duty lie. Moreover, there is probably a fairly large area within which parents may move without either obviously failing their duty or clearly exceeding it; but why should the (potentially considerable) differences within this range not make any difference at all to the extent of filial obligations?

In sum: the objections raised against the past parental sacrifices model fail to discredit it completely. In line with broadly shared intuitions, both reciprocity and gratitude are plausible elements in a complete account of filial obligations.

\subsection{The Special Relationship Model}

Since the friendship model of filial obligations has had such a prominent place in the debate from the beginning, I will also briefly discuss it here, before turning to variants of what I will call the 'special relationship model' that emphasize the special nature of the parent-child relationship as a parent-child relationship.

"Central to the friendship model," Dixon (1995, p. 83) writes, "is that the extent of filial obligations is determined by the extent of our friendly relations with our parents." Both English and Dixon also factor in parental needs and children's abilities and resources, but for English, once these are taken into account, all that matters is 'the extent to which there is an ongoing friendship' between parents and children (English 1979, p. 354). "[A]fter a friendship ends, the duties of friendship

\footnotetext{
15 See also Dixon (1995, p. 78): "That duty may coincide with inclination does not diminish its status as duty." And Sommers (1986, p. 449): "One may recognize one's duty in what one does spontaneously and generously."
} 
end.” (English 1979, p. 353) According to English, this applies equally to parentchild relations. But this means that it does not really make sense to speak of filial obligations. Friendship entails obligations (that are different from the obligations incurred by favours), and children have obligations towards their parents only insofar as there is a relation of friendship between them. The fact that one is their son or daughter is neither here nor there. At best, there is a contingent relation between people being related as parents and children and the chance that they have developed a friendship. English' friendship model, then, is an example of Sommers' DP (differential pull) model (see Section 2.3) that does not account for filial obligations as filial obligations. ${ }^{16}$

Dixon's friendship model improves upon English' model in some respects. He tries to answer the common objection that filial obligations do not end when the 'friendship' between parents and children ends. ${ }^{17}$ In Dixon's view, the same is true for friendships that were deep and long-lasting. We have residual duties to former friends in such cases, the moral basis of which is 'respect for our former friendships, our former friends and ourselves'. "To treat a former close friend as a stranger (...) is to discount our former friendship, and indirectly devalues both of us, since we both invested part of ourselves in the friendship." (Dixon 1995, p. 79) $\mathrm{He}$ also emphasizes that there are real duties of friendship; that friends are not, normally, motivated by duty does not mean there are no such duties. ${ }^{18}$ One of the main criticisms Dixon needs to deal with is the comment that parent-child relations are different from those between friends. Parent-child relations are characterized by inequality of various kinds-inequality in the sacrifices made for one another, in autonomy, in knowledge about the other, and (partly as a result of this) in power. Moreover, parents and children "lack the independence needed for one characteristic of deep friendships: a voluntary union between two separate people, who achieve a friendship by growing to know and appreciate each other" (Dixon 1995, p. 81). ${ }^{19}$ For Dixon, this does not invalidate the friendship model. Deep friendships may also have these features to some extent. "It would be wiser to recognise a multiplicity of types of friendship", of which parent-child relationships constitute a special kind (Dixon 1995, p. 81). And Dixon goes on to state that "[i]f one insists that the differences pointed out by Kupfer prevent parent-child relations from being

\footnotetext{
${ }_{16}$ As noted in footnote 5, a similar objection might apply to the past parental sacrifices model. Are filial obligations just instances of a general obligation to reciprocate or be grateful for other people's sacrifices made with a view to one's well-being? Moreover, are parental sacrifices merely accidental to the relationship? Against this one could argue that this model emphasizes the unique nature and extent of parental sacrifices; exceptional cases aside, there is no analogue for this in other relationships. So one could argue that the past parental sacrifices model draws our attention to the unique nature of the parentchild relationship (which English does not do), but abstracts one particular element from it, which receives all emphasis. On the other hand, even if parental sacrifices are (normally) unique in nature and extent, filial obligations may still be generated by those sacrifices only, regardless of who made them. This matter deserves further consideration that I cannot give it here.

17 This objection has been raised, for instance, by Callahan (1985, p. 34), and more recently by Collingridge and Miller (1997, p. 126) and Keller (2006, p. 264).

18 See footnote 15 .

19 These points about the difference between parent-child relations and relations of friendship are made by Joseph Kupfer (1990), and are also discussed by Zola (2001, p. 190).
} 
regarded as a type of friendship, only a minor modification of the friendship model will be required. (...) [A]ll that would be required would be to rename the model (...)" (Dixon 1995, p. 82). I would turn this around: there is no good reason to insist on a friendship model of filial obligations. Parent-child relations may indeed be characterized by a kind of friendship, but they typically have important features we do not normally associate with friendship (such as the various types of inequality and asymmetry inherent in them, and the way they come into existence and develop over time). If we want a model of filial obligations, and seek their basis in the nature of the parent-child relation, it makes more sense to look at what (typically) makes this relation special. ${ }^{20}$

Different views of what makes the parent-child relationship unique have been put forward. Callahan (1985) emphasizes the biological relationship, and also proposes intimacy as a source of obligation (with regard to the latter see also Nelson 2002). Gerber maintains that parents usually deserve gratitude, but also suggests that "the love that parents have for their children is in a rather special category, and may indeed create an actual right [to be cared for by their children] (...) albeit a minimal one" (Gerber 1990, p. 32). It could also be argued that convention is what makes the parent-child relationship unique, but I will leave this for the next section. In the remainder of this one I will discuss what I consider to be the most promising variant of the special relationship model, i.e., the special goods theory.

The term is Keller's, but the approach is hinted at by Nelson (2002), where he draws attention to parental needs that only the children may be able to fulfil. For other needs it may be justified to make collective provisions. "What filial obligations particularly concern are those parental needs that may not be satisfiable in any way apart from the maintenance of a relation of intimacy with their children." Claudia Mills, too, proposes a kind of special goods theory. Her central point is that it is a great good to participate in unchosen and unconditional(ly loving) relationships, of which family relationships are the most prominent example. We have prudential reasons to participate in such relationships and to make efforts to continue them (for in so doing we also provide this good to ourselves), and moral reasons "not to deny others the good of participating in such relationships with us" (Mills 2003, p. 149). She claims that "grown children owe their parents those things that flow from participating together in an unconditional, unchosen relationship, and not (generally) material goods that can be otherwise obtained"(Mills 2003, p. 149). Children owe parents only what only they can provide, namely the goods that are internal to the relationship, rather than, for instance, money, or other things one can in principle 'get from anywhere' (Mills 2003, p. 156).

Mills' view is problematic for a number of reasons. The main issue is that the fact that a certain kind of relationship is a great good is not in itself enough to establish an obligation to participate in it. Further argument is needed; she could have argued, for instance, that if a person ends her relationship with her parents, she deprives them of the good intrinsic to that relationship, and even positively harms them, given that they experienced their relationship to her as a good one. Mills also leaves important things unspecified, such as when a relationship must be considered

${ }^{20}$ Cf. Keller (2006, p. 264). 
'toxic', meaning that one cannot have an obligation to continue it (Mills 2003, pp. 160-161), and when (care-dependent) parents still 'participate' in the relationship with their children in such a way that the children, in participating in it, provide the good of the relationship not only to their parents, but also to themselves. $^{21}$

Keller offers the best developed version of the special goods theory, but in essence it is the same as Mills' account. The parent-child relationship holds special goods for both parents and children. 'Special' goods, rather than 'generic' goods, because "there are no other sources, or not many easily accessible sources, from which they can be gained" (Keller 2006, p. 266). Examples of these special goods are, for parents, 'the good of having your child, the one you raised, love and care about, make an effort to keep in touch', having traits in common, and parents being 'likely to identify with and have a special understanding of their children' (Keller 2006 , p. 266). For children " $[\mathrm{t}]$ here is a special value in having a parent from whom to seek advice", "[a]n ongoing healthy relationship with a parent can provide a link between your life's different stages" and "an understanding of the parents who produced you can enhance your understanding of yourself" (Keller 2006, p. 267). Both parents and children enjoy "the good of having someone who is especially committed to ensuring that your needs and interests will be met, in the particular way in which parents and children show each other concern" (Keller 2006, p. 267). Keller suggests that:

the reason why you have special duties to your parents is that you are uniquely placed to provide them with these goods, and find yourself in a relationship in which they have provided (and perhaps continue to provide) special goods to you. And the duties themselves are duties to provide the special goods to your parents, within the context of the reciprocal relationship that you and your parents share. (Keller 2006, p. 268)

Keller himself mentions two major difficulties with his account, the first regarding the scope: "Perhaps the special goods theory does not find filial duty in every place where it should." (Keller 2006, p. 271) For instance, when someone, through no fault of his own, would just happen to have no more concern for his parents' needs and well-being than for that of others, he would have no special duties according to the theory, because he would not be well-placed to provide the special goods. In such a case, Keller writes, "your duty might have a non-standard source" (such as legitimate expectations or social conventions) (Keller 2006, p. 272). The second concerns the question how duties flow from goods. Keller argues that "when you are uniquely placed to provide someone with an important good, you have a moral reason to do so, at least in some sense and other things being

\footnotetext{
21 The latter point is also important with regard to children's prudential reasons for participating in these relationships. Strangely, at one point Mills seems to make children's obligations partly conditional on the prudential reasons (Mills 2003, p. 163: "especially if I can provide it in a way that benefits me as well"). Another odd thing about Mills' view, given the stress she lays on the importance of investigating the nature of a relationship when trying to determine what obligations obtain within it, is that she believes exactly the same obligations hold between siblings, between parents and grown-up children, and between grown-up children and parents (i.e., both ways).
} 
equal", and that "it is not implausible to think that" this is all the more true in a special relationship, when the other has provided important special goods to you, and you can do the same without "too great a restriction of your ability to live a good life" (Keller 2006, p. 273). ${ }^{22}$

In the special goods theory there is a very clear relation between the source of filial obligations and their nature and extent. Filial obligations are ultimately contingent upon the existence of the kind of parent-child relationship in which the special goods arise; they do not simply come with the fact of being someone's child. Yet they really are filial obligations, having their source in the value of the special goods inherent in 'healthy' parent-child relationships. Children owe exactly those things their parents cannot get elsewhere; they owe them the continued provision of the special goods. I would note, however, that the special goods can sometimes be provided through generic goods, because sometimes it is who does something that makes the difference. ${ }^{23}$

It is also worth noting that Keller's model of filial obligations includes an element of reciprocity. Where he states the reason why we have special duties to our parents he explicitly mentions their having provided (or providing) special goods to us (Keller 2006, pp. 268, 273), referring to a 'reciprocal relationship' (Keller 2006, p. 268). Also, "[i]f your parents choose not to carry out their duties towards you, make unreasonable demands, or are otherwise to blame for the deterioration of the relationship (...) then your duties to provide the special goods to them is [sic] mitigated or dissolved" (Keller 2006, p. 269). So reciprocity seems to be part of the source or ground of filial obligations. And as noted above, where his account fails, Keller admits other possible grounds for filial obligations. (This is in line with the conclusions reached in Section 2.1 and, as we will see, in Section 2.3.)

Secondly, although the special goods theory captures an important element of the moral relationship between parents and children, it does seem to me that there is more to it than one's being in a particularly good position to provide certain special goods. For instance, the meaning that is derived from interaction with one's parents or children is important, as well as the mutual recognition. It seems forced to see such things in terms of being well-placed to provide special goods, the goods of meaning and recognition. This way of referring to it abstracts too much from the flow of the relationship, solidifying into 'special goods' currents that are part of the flow but not extricable from it. Relatedly, stating that 'the good of having your children around for Christmas' is the kind of good 'that your children are uniquely placed to provide' seems to lend this 'fact' a contingency, an almost accidental nature, that it plainly does not have.

To be sure, Keller makes clear that one's being well-placed to provide the special goods arises from, and is rooted in, the special relationship-but the language of special goods does not fully succeed in conveying this. The parent-child relationship is heavily charged with meaning, from which it derives much of its (moral) importance. ${ }^{24}$ In fact, it seems that some of the things mentioned by Keller

\footnotetext{
22 Daniels (1988, p. 32) writes that "children have [filial] obligations because they are in a unique position to help parents"; he holds beneficence to be the only plausible basis for filial obligations (cf. Allen 1991, p. 599).

23 Richards (2010), who also proposes a kind of special goods theory, acknowledges this.

24 Cf. Gerber (1990, p. 33).
} 
himself (and noted above), such as the fact that for children it is especially valuable to have a parent to ask for advice, or that an ongoing relationship with one's parents can provide a link between life stages, are more appropriately expressed in terms of the meaning(s) inherent in the parent-child relationship than in terms of special goods. There is meaning in this relationship at different levels, from the general to the detailed: children mean continuity of the family line, parents (often) mean safety and security-even if this is illusory; the world may appear as a colder place when both parents are gone. As in other long-term relationships, small gestures and phrases may carry a load of meaning - sometimes it is a burden-due to the shared history and memory. In between the most detailed and the most general are many meanings, often specific to the parent-child relationship as defined (to an important extent) by social conventions (see Sections. 2.3 and 3.2). For instance, parents are children's first role-models, inevitably setting standards for moral behaviour, career success, or good parenting. And for a child to reject these standards (which is very hard to do) is very hard to accept for most parents. Too much difference between parents and children frustrates the need to belong of both, since the family is one of the main foci of this need. ${ }^{25}$

That the parent-child relationship is so heavily charged with meaning also means that both parents and children have great power to do good as well as to harm each other. Both the good and the harm can be of many and complex kinds. For instance, in relationships of this kind there is the possibility of betrayal (cf. Goodin 1985, p. 89), which is another indication of the moral multifariousness of these relationships-a multifariousness that is not fully captured by the special goods account.

\subsection{The Conventionalist Model}

Christina Hoff Sommers' account of filial obligations is generally regarded as the main conventionalist account. I will limit myself to a discussion of her approach. ${ }^{26}$ Against English, Blustein, and others, Sommers argues for 'a strong notion of filial obligation', and for special moral relations in general. She is especially concerned with children's 'duty to honor and respect' their parents (Sommers 1986, p. 440).

Her argument for special obligations draws on a contrast between two opposing views of the moral domain, the domain consisting of 'moral patients' (in Warnock's terms) or all beings with 'ethical pull' (in Nozick's terms) (Sommers 1986, p. 443). ${ }^{27}$ According to Sommers, utilitarians and deontologists, although they may differ about the extent of the moral domain, agree about its nature. To show this Sommers considers, for the sake of simplicity, a domain consisting only of 'moral patients that are also moral agents' (Sommers 1986, p. 443). "Then it is as if we have a gravitational field in which the force of the gravitation is not affected by distance and all pairs of objects have the same attraction to one another." (Sommers

\footnotetext{
25 Baumeister ties the need to belong closely to people's need(s) for meaning in life, and identifies the family as a key source of meaning for most people (Baumeister 1991, pp. 145-46).

26 Confucian approaches (see Li 1997 and Wang 1998) are also to a great extent conventionalist, but I will not discuss them here, since my concern is with approaches - and with finding an approach-that might carry conviction in Western countries.

27 Sommers' references are to Warnock (1971, p. 152), and Nozick (1981, p. 451).
} 
1986, p. 443.) In other words: that someone is my mother, father, brother, sister, or friend, makes no difference to this person's ethical pull, or the pull (s)he ought to have for me-his or her pull is the same as anyone else's. The only legitimate reason why I might more often help my mother than a stranger in a faraway country is that it is easier for me to do so (and, I would add, my actions are more likely to be effective). This is the model of equal pull.

The opposing model Sommers calls differential pull. "In DP morality," Sommers explains, "the community of agents and patients is analogous to a gravitational field where distance counts and forces vary in accordance with local conditions." According to this model, "the ethical pull of a moral patient will always partly depend on how the moral patient is related to the moral agent on whom the pull is exerted. Moreover," Sommers continues-and here she adds a conventionalist element to the model that is not necessarily part of it - "the 'how' of relatedness will be determined in part by the social practices and institutions in which the agent and patient play their roles." (Sommers 1986, p. 445) The DP model recognizes "the crucial role of conventional practice, relationships, and roles in determining the nature and force of moral obligation" (Sommers 1986, p. 445).

She goes on to explain filial duties by discussing another kind of special obligation, namely the self-imposed one resulting from a promise. A.I. Melden (1977) explains this kind of obligation in terms of a failure to respect people's right to noninterference. He assumes that everyone has 'the right not to be interfered with in the pursuit of his or her noninvasive interests' (Sommers 1986, p. 446). To make a promise 'gives the promisee the action as his own'; thus, to break a promise is "tantamount to interfering with or subverting endeavours he [the promisee] has a right to pursue" (Melden 1977, p. 47). So the positive duty of promise keeping is grounded in the 'minimalist negative obligation of noninterference' (Sommers 1986, p. 446).

Sommers applies this to other special obligations: the negative duty of noninterference "is refracted by the parochial situation as a special duty which may be positive in character, calling on the moral agent to act or refrain from acting in specific ways toward specific moral patients" (Sommers 1986, p. 446). The core of her approach is this:

The presumption of a special positive obligation arises for a moral agent when two conditions obtain: (1) In a given social arrangement (or practice) there is a specific interaction or transaction between moral agent and patient, such as promising and being promised, nurturing and being nurtured, befriending and being befriended. (2) The interaction in that context gives rise to certain conventional expectations (...). (Sommers 1986, p. 446)

Furthermore, "because it does violence to a social role, a filial breach is more serious than a breach of promise. (...) Causing humiliation is a prime reason why filial neglect is tantamount to active interference" (Sommers 1986, p. 447).

The 'sentimentalist' (like English or Blustein) argues for a morality sensitive to special relations, but "ignores the extent to which the 'care perspective' is itself dependent on a formal sense of what is fitting and morally proper" (Sommers 1986, p. 450). In other words, there is an important and irreducible conventional aspect to parent-child relations, and this is an important determining factor with regard to both 
filial obligations and the various feelings and sentiments that exist between parents and children. Sommers believes that, compared to the EP model, her DP model can "more plausibly account for our preanalytic moral judgments concerning what is right and wrong in a wide variety of real cases", as well as "for the discriminate duties that correspond to specific social roles and expectations" (Sommers 1986, p. 452).

Finally, Sommers argues that the DP model can deal with the danger of ethical relativism by adopting the deontological principle of noninterference as a standard by which traditional arrangements in various societies may be judged and criticized: "Arrangements that are essentially invasive are unjust and do not confer legitimacy on what is expected of those who are party to them." (Sommers 1986, p. 453) She acknowledges the conservatism of her conventionalist approach, and believes this makes it somewhat hospitable to ethical relativism, though without yielding to it. She in fact argues for a form of ethical contextualism (Sommers 1986, p. 454).

I see two serious problems for Sommers' model of filial obligations. The first is that, even if Melden's account of the duty of promise-keeping were adequate, it is doubtful to what extent special duties in the relational sphere are comparable to this duty. Promises are things one makes oneself and can decide not to make. Parents, on the other hand, one simply has, and if this comes with filial duties, this makes them unlike the duty of promise-keeping. Sommers believes filial obligations, like promises, are grounded in the negative obligation of noninterference. Even if one accepts Sommers' argument that when children are negligent in their filial obligations, this is humiliating for their parents because it diminishes their entitlements (Sommers 1986, p. 447), is this really most plausibly described as a violation of the duty of noninterference? In some sense, all actions contrary to conventional expectations are a form of interference. But it seems that what is morally salient in this case is not the interference as such, but the importance of what is expected, which is rooted in the importance and meaning of the parent-child relationship as such (whether conventionally defined or not).

The second problem is that to do violence to a social role is only a bad thing if we accept the value of the social role and its specific definition. What if the definition of the social role is morally questionable? Sommers' answer is to argue that "arrangements that are essentially invasive are unjust" and therefore engender no obligations. But if what is appropriate within parent-child relationships is (and must be) conventionally determined, how can we have a nonconventional, objective, view of what counts as 'invasive', of what are (un)acceptable definitions of the roles of parent and child? I do not wish to suggest that Sommers should be able to solve this problem completely, but merely that she should at least have acknowledged it, especially because her strong emphasis on the importance of convention makes her account particularly vulnerable to it.

These comments, however, do not invalidate the claim that conventional definitions of social roles make a difference to filial obligations. That strong expectations exist within parent-child relations makes for (mutual) vulnerability and therefore power-not least power to hurt and harm. These expectations are undeniably shaped by social conventions, which means that the obligations they give rise to are also at least indirectly conventionally based. This holds at least when the expectations are legitimate. But it is plausible to think that such expectations can be legitimate-that the social roles of parent and child are not inherently problematic, regardless of their culturally and historically contingent definition. 
Moreover, I accept that the moral importance of these conventions is not exhausted by their indirect effect on filial obligations, through expectations and the beneficial or harmful consequences of their (non)fulfilment. If there is a special value or meaning (or if there are special goods) inherent in the parent-child relationship-which seems to be true-this is only by the grace of there being such a thing as a 'parent-child relationship', and this is largely due to there being these roles and a specific definition of them. Role definitions are not the whole of the relationship, but they are constitutive of it. An adequate model of filial obligations cannot ignore this.

\section{A Contextual, Pluralist Model}

In this section I will explain and defend the model of filial obligations shown schematically in Section 3.1, which is contextual in the sense that it situates filial obligations in the larger societal (both cultural and structural/institutional) context, and pluralist in that it recognizes multiple (possible) sources or bases of filial obligations. It integrates the valuable elements of the models discussed above into one model, and includes often neglected factors, such as the relation between filial obligations and institutional arrangements, and the connection between these obligations and social justice issues. In other words, the model is synthetic; it accepts the validity of various perspectives, while at the same time situating them in a broader context. It is intended to facilitate a deeper understanding of filial obligations.

\subsection{The Model}

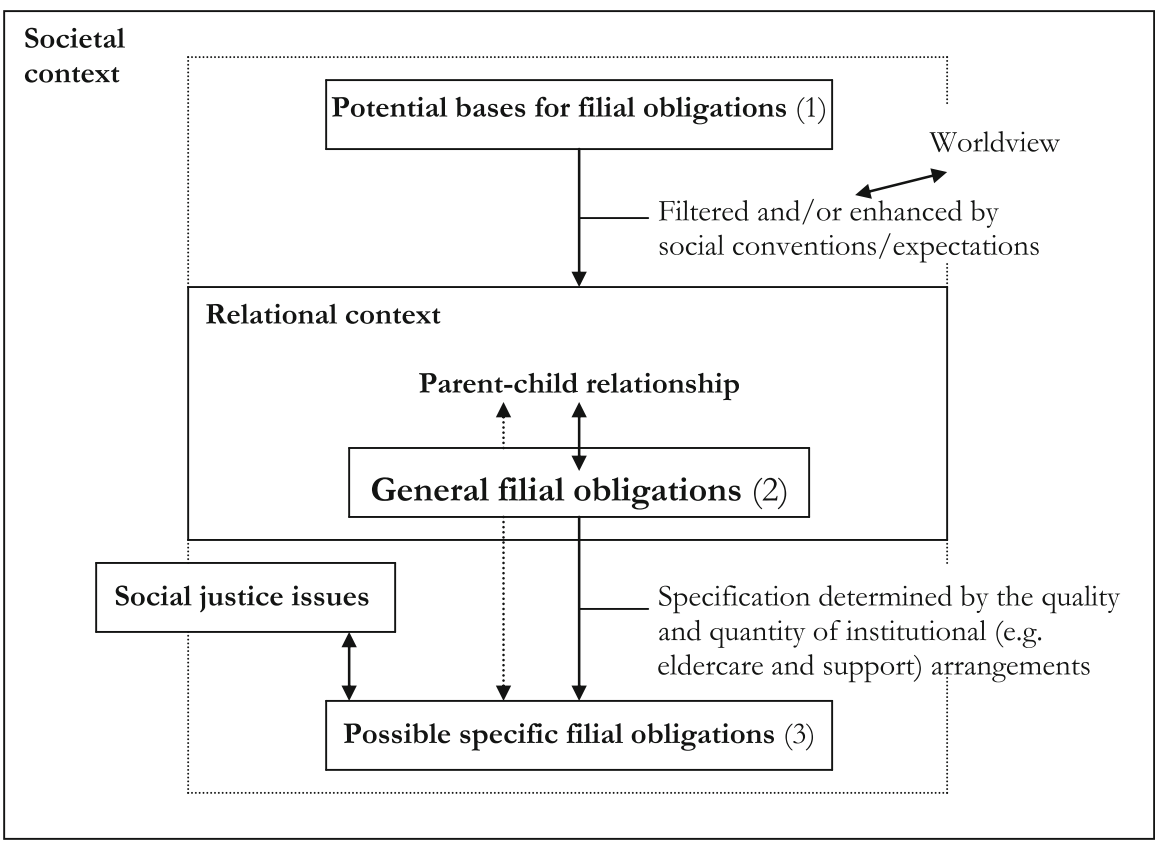


1. These are things that, under certain circumstances (including, for instance, the needs, abilities, and resources of both parents and children), and given a certain societal context, provide a basis for (general and specific) filial obligations. Possible bases for filial obligations (such as past parental sacrifices, or the special relationship between parents and children) do not immediately lead to (general) filial obligations, but are, as it were, filtered and/or enhanced by social conventions and the expectations to which these give rise, or which they allow to arise. Of course these potential bases for filial obligations are not literally to be imagined as free-floating, and then picked up and either diminished or enhanced by social conventions; rather, we see that the same bases for filial obligations are virtually universally acknowledged, but given different emphases in different societies. Social conventions are (not necessarily fully consistently) embedded in a shared worldview-as becomes clear when we compare 'Western' accounts of filial obligations with 'Eastern' accounts. In the latter, for instance, past parental sacrifices are an extremely important source of filial obligations. ${ }^{28}$ Although in the previous section I have-in line with common practice-discussed conventions as a possible basis or source of filial obligations, in this model they can helpfully be seen as playing the role of a mediating factor, either strengthening or weakening the connection between (virtually universally acknowledged) possible bases of filial obligations and these obligations. I do not believe social conventions and expectations fully determine the nature and extent of filial obligations-i.e., the model is not relativistic, but (merely) contextual. But, as argued in Section 2.3, they have a considerable direct and indirect effect; the question of the relation between social conventions and expectations on the one hand, and filial obligations on the other, is also taken up in Section 3.2.

To illustrate the above with another example: parental neediness due to poverty or ill health is a generally accepted basis of filial obligations in most, if not all, cultures. It is the basis for a general filial obligation to support one's parents; in more collectivistic societies, however, this obligation is taken to be much stronger than in individualistic societies, where individual autonomy and independence are stressed (De Valk and Schans 2008, pp. 53-54). Different conventions and expectations, in turn related to specific ideologies and worldviews on the one hand, and different (long-standing) institutional arrangements on the other, 'mediate' between parental neediness and filial obligations. The existence of particular institutional arrangements is an important determinant of the nature and extent of the specific filial obligations that flow from the general ones. Thus, in De Valk and Schans' study in the Netherlands, $57 \%$ of Turkish immigrants (aged between 50 and 80) and $51 \%$ of Moroccans agreed with the statement that children 'should care for sick parents', against $11 \%$ of the Dutch respondents in this age group. And while

\footnotetext{
${ }^{28}$ Gerber (1990, p. 29) mentions an interesting empirical study, in which Vietnamese and American children were asked to complete the sentence "I love my mother, but...". "The American children in general completed the sentence with some sort of (usually trivial) complaint against their mothers. The Vietnamese children never did. Instead, they supplied such endings as 'I can never repay my debt to her' or 'I am too weak and small to repay her yet."”.
} 
$44 \%$ of the Turks and $34 \%$ of Moroccans stated that 'parents should be able to live with children when old', only $3 \%$ of the Dutch agreed (De Valk and Schans 2008, p. 59) What is important here is not just that people in fact $d o$ things differently or hold different beliefs about how things ought to be done, but that different moral obligations do indeed obtain in different contexts. Both social conventions and institutional arrangements have moral relevance.

2. General filial obligations are, for instance, the obligation to 'honour and respect' one's parents, to be grateful and express gratitude, to reciprocate, to give one's parents (and their needs and interests) special consideration, and so on. Filial obligations are not something separate from the parent-child relationship, but are part of it; they belong to the moral dimension of the relationship. They vary (at least to some extent) with the nature and quality of the relationship. In extreme cases, such as cases of child-abuse, filial obligations are wholly absent or annulled, but normally there are filial obligations. The extent of a general obligation (to be grateful, for instance, or to give one's parents special consideration) may also differ; it is not a matter of all or nothing. For instance, a child that was not given much special consideration by its parents cannot (morally) be expected to give as much special consideration to them as a child that was more fortunate in this regard. Yet this remains a general filial obligation, for it remains unspecified what form its fulfilment could or (in certain circumstances) should take.

Not only do filial obligations vary with the nature and quality of the parentchild relationship; the converse is also true, for that relationship depends in part on the way children fulfil their filial obligations (as it depends on the way parents fulfil parental obligations). The relational context in which filial obligations arise and exist is embedded in the societal context, which to an important extent defines the (possible) nature of the parent-child relationship. By the dotted lines I have tried to express the idea that, despite the 'mediation' in the form of filtering and/or enhancement on the one hand and specification on the other, neither the bases of filial obligations nor specific filial obligations are to be located outside of the relational context. For the latter, that is because they belong to the moral dimension of the parent-child relationship as such, and for the former it is because they arise within the context of the relationship. (How could it be otherwise, with parental sacrifices, for instance, or with the special goods inherent in the relationship?)

3. That children normally have (general) filial obligations leaves unspecified what specific obligations they have, what form the fulfilment of their general filial obligations should take. Should you be in touch regularly? More specifically, should you visit your parents regularly? (How often?) Or is it enough to call them occasionally, rather than call on them? Should you help them out financially? Should you do their administration? The answer to such questions naturally depends on both parents' and children's needs, abilities, and resources, and on the nature and quality of the relationship. But it also depends crucially on the quality and quantity of institutional arrangements benefiting the elderly, organizing eldercare, and supporting informal care arrangements 
including care provision by children to their parents. (And these, of course, influence needs, abilities, and resources.) Where eldercare is adequately arranged on a collective level, through care institutions and financial and other support, children's specific filial obligations constitute a much more limited set than in the absence of such arrangements. The general filial obligations would remain, however, and certain specific obligations would still follow from them-such as an obligation to pay regular visits to an elderly parent in a nursing home. (See Section 3.3.) Finally, it should be noted that even the 'specific' obligations cannot always be described in a very specific mannernot more specific than an obligation to pay 'regular' visits, for instance. But when a parent is especially lonely, and it is clear what the effect of a child's visits is (and various other considerations have been taken into account besides), it may be possible to specify this kind of obligation somewhat further, by saying that 'regular' means 'at least once a week', for instance. But I should immediately add that such specific obligations cannot be established from the outside, by a third party, for it requires intimate knowledge of a host of factors related to and influencing the relationship between the parent and child in question-knowledge that is simply not available to outsiders. Rough estimates of whether someone else meets his filial obligations may sometimes be possible, but never very precise ones.

\subsection{Social Conventions and Filial Obligations}

In Western countries, one of the things that makes the issue of filial obligations particularly relevant is that there may be significant differences between the expectations of elderly immigrants and their children's perception of their obligations to their parents. What if an adult Moroccan woman who was brought to Europe at a very young age does not accept the conventional Moroccan view of filial obligations? Does she still have them?

A first response might be: that depends on whether the conventions and expectations were legitimate to begin with. But how do we assess that? Presumably, parental expectations are legitimate when they correspond with filial obligations. Yet one of the claims I made was that the nature and extent of filial obligations is partly determined by social conventions and the expectations to which these give rise. How do we solve this conundrum ? $^{29}$

We must adopt a different view of the legitimacy of social conventions and expectations. I can only offer a very brief sketch of such a view here. One criterion for the legitimacy of conventions is that the social system of which the conventions are an integral part should not contain or produce significant ${ }^{30}$ harm or injustice as a result of the presence of those conventions. Another is that the conventions are of

\footnotetext{
29 I thank an anonymous referee for The Journal of Ethics for pressing me on this point.

30 Arguably, a certain 'amount' of harm or injustice does not disqualify conventions altogether, if they have a 'proven' value (see the next criterion and the last paragraph of Section 2.3). Not all things that might be called a harm or an injustice are equally morally significant (compare a nuisance to a lack of food, or racial discrimination to minor but undeserved socio-economic inequalities).
} 
value, for instance, by ordering human relationships and interactions in such a way that important needs (both material and immaterial) are met. When these conditions are met, and the conventions are well-established and hardly ever departed from, so that they 'naturally' give rise to certain expectations, both the conventions and the expectations based on them can be considered legitimate. Filial obligations can then be (partly) determined by them without circularity. ${ }^{31}$

So, returning to our Moroccan woman, it would be morally problematic for her to simply reject the filial obligations ascribed to her without warning from one moment to another, because parental (and other people's) expectations would be greatly frustrated, which-assuming these expectations and the conventions in which they are rooted are legitimate in the above sense-would be a bad thing, with moral relevance. ${ }^{32}$ However, if (under the influence of the society in which she lives and her European peers and friends) she comes to hold different views, and accordingly detaches herself from the practices related to the conventional views-including those beneficial to her-conventional norms cease to apply fully to her.

This entails the at first sight perhaps radical conclusion that whether conventional norms apply to someone depends in part on this person's acceptance of them and the worldview from which they stem. This is the case when the following conditions apply: (1) The (non-)acceptance is fairly consistent, as opposed to haphazard or selfserving; for instance, it applies not just to the norms that would burden him or her, but to all norms affected by acceptance of the broader ethical outlook and the worldview in which they are embedded. In other words, (s)he accepts all intrinsic consequences of her (non-)acceptance-but explicitly not included here are extrinsic consequences such as being ostracized. (2) There is room, from an ethical perspective, for different reasonable views on the subject (which is certainly the case when it comes to filial obligations), and she holds a reasonable, morally acceptable view.

So, on the one hand, it is certainly possible to 'escape' the influence of specific conventional norms. On the other hand, acceptance-including tacit acceptance-of (legitimate) conventional norms implies that one is (to some extent) bound by obligations that do not apply to people who do not accept those norms. This is, firstly, because of the expectations to which the conventions give rise, which one sustains by one's acceptance of the conventional norms, and the frustration of which would result in harm; and secondly, because due to one's acceptance of the conventional norms the parent-child relationship would remain defined by them. ${ }^{33}$ The nature of the parent-child relationship would be defined by these norms, and

\footnotetext{
31 Thus we can see how conventions may play a role in determining what is appropriate within parentchild relationships, without themselves providing the standard for their own appropriateness. Of course, justifying a non-conventional standard remains a difficult task, as noted in the discussion of Sommers' approach (Section 2.3).

32 If parental expectations are illegitimate, children may still have moral reasons to take them into account, because frustrating those expectations would still hurt their parents. Whether they have such reasons will depend on the nature of the relationship; the word 'obligation' will at any rate be too strong in such a case.

33 The elderly immigrants' views on filial obligation may also change, of course, as Ingrid Robeyns rightly pointed out to me. But they tend to be less liable to change than those of their children; I focus, therefore, on situations in which there is a divergence between parents' and children's expectations.
} 
this would influence filial obligations to the extent that these depend on the special meaning and value of the relationship.

I would like to stress, once again, that this does not amount to moral relativism. First of all, I take the harm principle to be universal. The definition of what constitutes harm is to some extent contingent on time and place, and the same goes, therefore, for what may cause harm. But that does not make the harm principle any less universal.

Furthermore, that filial obligations depend (in part) on the nature of the parentchild relationship, and that this depends on social conventions, does not make features of the parent-child relationship any less objective. A specific parent-child relationship really has these features, even if it has them 'only' because of certain conventions. The conventional basis is not a reason to question the objectivity of these features, but it is a reason to question the import of the fact that these features are present. Here it becomes important to distinguish what is just in the specific situation, given existing conventions ('imperfect' or 'nonideal' justice) and what would be ideally just - both in terms of ideal conventions and the specific situations these could give rise to. Thus one may recognise that the (most) just thing to do in a given situation is wholly or partially to comply with less than ideally just conventions, while of course also recognising that ideally, these conventions would not exist. The most just course of action would probably include some effort towards altering these conventions. ${ }^{34}$

\subsection{Social Justice and Filial Obligations}

A full discussion of the relations between filial obligations and issues of social justice would address egalitarian concerns, issues of gender justice and intergenerational justice, and that of ideal versus non-ideal conceptions of justice. I can only hint at some of the connections here.

Wang (1998) places filial obligations in a broader context, asking who should take care of the elderly: the family, or society as a whole? He asks two questions with regard to the latter: (1) should the society have that burden? (2) can the society or the government really provide adequate care for the elderly? He has doubts both about the adequacy of the care that can be given by society, and about whether society will be able to bear the burden. Interestingly, Thompson (2003, p. 13) doubts whether family care would ensure adequate care for all elderly. Which care arrangement is best is to a large extent an empirical matter, which I cannot go into here. Suffice it to say that it is not obvious that being cared for by one's children is always better for elderly parents than to be cared for by professionals in an institution or some other living arrangement, nor that the latter is obviously better than the former. Most people see institutional care as far from ideal, and not without

\footnotetext{
34 As in the brief sketch I gave of criteria for the legitimacy of social conventions, I here assume, without being able to argue for it in this article, that it is possible to formulate criteria of justice that are not wholly culturally relative; though I should add that the distinction between ideal and nonideal justice does not necessarily depend on this.
} 
reason, but it has also been clear for some time that family caring can cause severe stress and various problems both for carers and the cared-for. ${ }^{35}$

With regard to eldercare policy it is important to note that a stress on filial obligations tends to increase gender inequality, because it is mostly daughters who take on the responsibility to care for their parents (Lye 1996, pp. 88-89). Economic inequality is also reinforced where the elderly are cared for mainly by their children, since children of poor parents are more likely to be poor themselves, and therefore unable to assist their parents in financially burdensome ways. It goes without saying that policies stressing filial obligations over collective care arrangements may overlook the fact that not all elderly have children to take care of them, and that not all children will fulfil their filial obligations. Moreover, the extent of filial obligations also depends on the way society is structured, apart from eldercare arrangements. Where society is structured such as to make it very difficult for people to take time or find energy to care for their parents, it would be disingenuous to place much emphasis on filial obligations-which is a point of critique on recent policy in many Western countries.

The question which specific filial obligations children have, if any, cannot be answered without taking considerations such as the above into account. Children may have certain obligations in a non-ideal situation which, ideally, they should not have-for instance, because on a macro-level it reproduces or even enhances socioeconomic inequality. Similarly, it seems plausible that where care for the elderly is adequately arranged on a collective level, through care institutions and financial and other support, children have far less filial obligations than in the absence of such arrangements. Some types of specific filial obligations are always likely to remain however; obligations to stay in touch, pay visits, take care of (minor) practical matters, and so on.

Where collective arrangements are absent or inadequate, and filial duties therefore more numerous and expansive, children may have these duties while at the same time being under an obligation (together with others) to strive for better collective arrangements. Like duties that flow from less than just social conventions they are non-ideal duties, that one only has because the situation is non-ideal, and as long as this is so-but one has them even while one is under an obligation to work towards a situation in which one does not have them.

\section{Conclusion}

The central question any model or theory of filial obligations needs to answer is why and how the specific nature of the parent-child relationship gives rise to (special) obligations. Even the different variants of the past parental sacrifices model can be seen as offering an answer to this question, albeit an answer that may be much more readily compatible with the EP model of the moral domain than that given by the other approaches. The best attempt at an answer that the literature offers is provided by the special goods theory, yet even in its most detailed elaboration (Keller's) it is

\footnotetext{
$\overline{35}$ See, for instance, Steinmetz (1988) and Abel (1989).
} 
far from comprehensive, and employs a language that runs the risk of distorting what it aims to capture.

At this point I do not have a fully adequate answer either. A purely abstract beginning of an answer would be that the parent-child relationship tends to be such that both parents and children have great power both to harm or hurt each other and to create value and meaning for each other, and that these are obviously morally relevant facts. The contextual, pluralist model I presented shows what elements ought to go into a more detailed and concrete elaboration of an answer. Such an elaboration would also need to rely on a realistic, empirically informed view of parent-child relations. For instance, Adam Smith's observation of the affective asymmetry of the parent-child relationship, that "Nature, for the wisest purposes, has rendered, in most men, perhaps in all men, parental tenderness a much stronger affection than filial piety" (1982, p. 142; III.3.13), if it points to something that is true in our day and age, might cast doubt on the fairness and feasibility of Richards' (2010, p. 240) proposal that children ought to give parents a place in their affections roughly equal to the place they had in their parents' affections. Another example might be the potential moral relevance of the (sociological and psychological) ambivalence of parent-child relations, a feature little stressed by writers on filial obligations, but receiving increasing attention in family studies (Luescher and Pillemer 1998; Willson, Shuey, and Elder 2003; Fingerman, Pitzer et al. 2008).

Finally, it seems to me that the study of filial obligations should confront the question of the moral importance of such expressions as 'but she is your mother', and 'I am still his son'-expressions often given in explanation, justification, or exhortation, that are charged with normative significance. What we need to know is to what extent filial obligations are moral obligations, and whether there may also be non-moral filial obligations, whether, in other words, the moral vocabulary can fully capture the normativity inherent in these expressions.

Acknowledgments Thanks are due to Martijn Boot, Anca Gheaus, and Ingrid Robeyns, as well as two anonymous referees for The Journal of Ethics, for their helpful comments on earlier versions of this article. I have also benefited from discussions with Kees Schinkel. This article was written in the context of Ingrid Robeyns' VICI project Social Justice and the New Welfare State, financed by the Netherlands Organisation for Scientific Research (NWO).

Open Access This article is distributed under the terms of the Creative Commons Attribution License which permits any use, distribution, and reproduction in any medium, provided the original author(s) and the source are credited.

\section{References}

Abel, Emily K. 1989. Family care of the frail elderly: Framing an agenda for change. Women's Studies Quarterly 17: 75-86.

Abelson, Raziel. 1982. To do or let happen. American Philosophical Quarterly 19: 219-228.

Allen, Jay M. 1991. Am I my parent's keeper? An essay on justice between the young and the old (review of Daniels 1988). Brigham Young University Law Review 1: 587-600.

Aronson, Jane, and Sheila M. Neysmith. 1997. The retreat of the state and long-term care provision: Implications for frail elderly people, unpaid family carers and paid home care workers. Studies in Political Economy 53: 37-66. 
Baumeister, Roy F. 1991. Meanings of life. New York: The Guilford Press.

Berger, Fred R. 1975. Gratitude. Ethics 85: 298-309.

Blackstone, William, Sir. 1893 [1765]. Commentaries on the laws of England in four books, Volume 1. Philadelphia: J. B. Lippincott Co. Available online at the Online Library of Liberty: http:// oll.libertyfund.org/index.php?option=com_staticxt\&staticfile=show.php\%3Ftitle=2141\&Itemid= 99999999. Accessed 19 Apr 2012.

Blustein, Jeffrey. 1982. Parents and children: The ethics of the family. Oxford: Oxford University Press.

Callahan, Daniel. 1985. What do children owe elderly parents? The Hastings Center Report 15: 32-37.

Collingridge, Michael, and Seumas Miller. 1997. Filial responsibility and the care of the aged. Journal of Applied Philosophy 14: 19-128.

Daniels, Norman. 1988. Am I my parents' keeper? An essay on justice between the young and the old. Oxford: Oxford University Press.

De Valk, H.A.G., and Djamila Schans. 2008. 'They ought to do this for their parents': Perceptions of filial obligations among immigrant and Dutch older people. Ageing and Society 28: 49-66.

Dixon, Nicholas. 1995. The friendship model of filial obligations. Journal of Applied Philosophy 12: 77-87.

English, Jane. 1979. What do grown children owe their parents? In Having children: Philosophical and legal reflections on parenthood, ed. Onora O’Neill, and William Ruddick, 351-356. Oxford: Oxford University Press.

Fingerman, Karen L., Lindsay Pitzer, et al. 2008. Ambivalent relationship qualities between adults and their parents: Implications for both parties' well-being. Journal of Gerontological Sciences, Series B: Psychological Sciences and Social Sciences 63: 362-371.

Gavrilov, Leonid A., and Patrick Heuveline. 2003. Aging of population. In The encyclopedia of population, ed. Paul Demeny, and Geoffrey McNicoll. London: Macmillan.

Gerber, Rona M. 1990. Gratitude and the duties of grown children towards their aging parents. International Journal of Applied Philosophy 5: 29-34.

Goodin, Robert E. 1985. Protecting the vulnerable: A reanalysis of our social responsibilities. Chicago: University of Chicago Press.

Guberman, Nancy, and Jean-Pierre Lavoie. 2010. The denaturalization of care: The new culture of care among baby-boomer caregivers in Quebec. Paper presented at the conference Transforming care: Provision, quality and inequalities in late life, Danish National Centre for Social Research, Copenhagen, 21-23 June 2010.

Holstein, Martha. 2000. Home care, women, and aging: A case study of injustice. In Mother time: Women, aging, and ethics, ed. Margaret Urban Walker, 227-244. Lanham: Rowman and Littlefield Publishers.

Human Development Report. 2009. Overcoming barriers: Human mobility and development. New York: United Nations Development Programme.

Jecker, Nancy S. 2002. Taking care of one's own: Justice and family caregiving. Theoretical Medicine 23: $117-133$.

Keller, Simon. 2006. Four theories of filial duty. The Philosophical Quarterly 56: 254-274.

Kupfer, Joseph. 1990. Can parents and children be friends? American Philosophical Quarterly 27: 15-26.

Le Bihan, Blanche, and Claude Martin. 2010. Transformations of long term care policies in Europe: A qualitative analysis of working caregivers of dependent elderly parent(s) in France, Portugal, Italy and the Netherlands. Paper presented at the conference Transforming care: Provision, quality and inequalities in late life, Danish National Centre for Social Research, Copenhagen, 21-23 June 2010.

Levy, Martin R., and Sara W. Gross. 1979. Constitutional implications of parental support laws. University of Richmond Law Review 13: 517-531.

Li, Chenyang. 1997. Shifting perspectives: Filial morality revisited. Philosophy East and West 47: 211-232.

Luescher, Kurt, and Karl Pillemer. 1998. Intergenerational ambivalence: A new approach to the study of parent-child relations in later life. Journal of Marriage and Family 60: 413-425.

Lye, Diane N. 1996. Adult child-parent relationships. Annual Review of Sociology 22: 79-102.

Malm, H.M. 1991. Between the horns of the negative-positive duty debate. Philosophical Studies 61: 187-210.

Melden, A.I. 1977. Rights and persons. Los Angeles: California University Press.

Mills, Claudia. 2003. Duties to aging parents. In Biomedical ethics reviews: Care of the aged, ed. James M. Humber, and Robert F. Almeder, 147-166. Totowa: Humana Press. 
Nelson, James Lindemann. 2002. Filial obligations. In The MacMillan encyclopedia of aging, ed. David J. Ekert. London: MacMillan.

Ng, Sik Hung. 2002. Will families support their elders? Answers from across cultures. In Ageism: Stereotyping and prejudice against older persons, ed. Todd D. Nelson, 295-309. Cambridge: The MIT Press.

Nozick, Robert. 1981. Philosophical explanations. Cambridge: Harvard University Press.

Okin, Susan Moller. 1989. Justice, gender, and the family. New York: Basic Books.

Post, Stephen G. 1989. What children owe parents: Ethics in an aging society. Thought 64: 315-325.

Richards, Norvin. 2010. The ethics of parenthood. Oxford: Oxford University Press.

Rummery, Kirstein. 2010. Personalisation, commodification and care ethics: A gendered comparative analysis. Paper presented at the conference Transforming care: Provision, quality and inequalities in late life, Danish National Centre for Social Research, Copenhagen, 21-23 June 2010.

Simmons, A. John. 1979. Moral principles and political obligations. Princeton: Princeton University Press.

Simonazzi, Annamaria. 2010. Home care and cash transfers: the search for a sustainable elderly care model. Paper presented at the conference Transforming care: Provision, quality and inequalities in late life, Danish National Centre for Social Research, Copenhagen, 21-23 June 2010. Forthcoming in: Gender and well being: interactions between work, family and public policies, eds. Addis, E., Degavre, F., Elson, D., Eriksen, J., and P. de Vilotta. Farnham: Ashgate (publication date unknown).

Smith, Adam. 1982 [1759]. The theory of moral sentiments, eds. D.D. Raphael and A.L. Macfie. Indianapolis: Liberty Fund.

Sommers, Christina Hoff. 1986. Filial morality. The Journal of Philosophy 83: 439-456.

Steinmetz, S.K. 1988. Duty bound: Elder abuse and family care. Thousand Oaks (CA): Sage Publications.

Thompson, Janna. 2003. Obligations to the elderly and generational equity. Working paper, Centre for Applied Philosophy and Public Ethics, at http://pandora.nla.gov.au/pan/23308/20030815-0000/ www.csu.edu.au/faculty/arts/cappe/PDF\%20Files/Thompson4.pdf. Accessed 19 Apr 2012.

Wang, James. 1998. The Confucian filial obligation and care for aged parents. In: Paper presented at the 20th world congress of philosophy, Boston; available online at http://www.bu.edu/wcp/Papers/ Comp/CompWang.htm. Accessed 19 Apr 2012.

Warnock, Geoffrey J. 1971. The object of morality. London: Methuen.

Wellman, Christopher Heath. 1999. Gratitude as a virtue. Pacific Philosophical Quarterly 80: 284-300.

Wicclair, Mark R. 1990. Caring for frail elderly parents: Past parental sacrifices and the obligations of adult children. Social Theory and Practice 16: 164-190.

Willson, Andrea E., Kim M. Shuey, and Glen H. Elder Jr. 2003. Ambivalence in the relationship of adult children to aging parents and in-laws. Journal of Marriage and Family 65: 1055-1072.

Zola, Charles. 2001. Geriatric filial piety. International Journal of Applied Philosophy 15: 186-204. 